\title{
Соња Петровић
}

Data przesłania tekstu do redakcji: 31.12 .2012 Data przyjęcia tekstu do druku: 19.05 .2013

spetrovic@fil.bg.ac.rs

\section{Топос скривене милостиње у старој српској књижевности}

\begin{abstract}
Petrović Sonja, Topos skrivene milostinje u staroj srpskoj književnosti (The Topos of Clandestine Charity in Medieval Serbian Literature). „Poznańskie Studia Slawistyczne” 5. Poznań 2013. Adam Mickiewicz University Press, pp. 267-279. ISBN 978-83232-2636-9. ISSN 2084-3011.

Charity and almsgiving, as the religious and social act of philanthropy and concern for the salvation of the soul, were one of the obligatory and permanent duties of rulers in the Middle Ages. Serbian medieval rulers were known for their numerous charitable donations to the poor, sick, old, widows, pilgrims, needy, as well as builders of churches, monasteries, hospitals. Many of these charitable deeds of the Serbian rulers became the subject of Serbian medieval literature. The topos of clandestine charity was particularly popular, since it well represented the beneficence and clemency of Serbian rulers, their piety and their respect for the poor. Disguised as beggars, several Serbian rulers (particularly Milutin, Stefan Dečanski, and Stefan Lazarević) were helping the poor by night, by giving them alms. These topoi are observed in hagiographies and church poetry, as well as in folklore and mythology. The hero in the beggar's clothing is related to the international story model of deities or demons that travel the world and test the people.
\end{abstract}

Keywords: topoi; clandestine charity; old Serbian literature; Serbian medieval rulers; almsgiving; the poor; folklore

Као социјални и религиозни чин милосрдног даривања, милостиње и доброчинства су били дужност владара од најстаријих времена. Милосрдним делима владари су практично решавали проблем сиромаштва, а с друге стране бринули су се о спасењу своје душе, будући да „сиромах представља лик Христа, док је милосрђе подражавање Христа” (Патлажан 2006: 37). Отуд владари, црквени великодостојници и добротвори граде болнице, прихватилишта за сиромашне и ходочаснике, у типицима одређују приходе за њихово издржавање, 
редовно угошћују сиромахе за својом трпезом и дарују их, остављају богата завештања у добротворне сврхе, што све има важну улогу у плану спасења.

У старом српском друштву милостиње, доброчинства и старање о социјално угроженима схватани су као вид спасења душе. Древна установа гостопримства је почивала на веровању да гост оличава божанство које треба умилостивити. Веровало се да су убоги под божанском заштитом, па предусретљиво понашање према њима може да прибави божанску милост. Са примањем хришћанства су усвојене старије традиције да је старање о угроженима обавеза цара, али и сваког верника који се нада спасењу душе. Обавезе владара да чине доброчинства сиромашнима и сиротима, да их хране на свом двору, законски штите и примају њихове жалбе, биле су прописане Душановим закоником (чл. 28, 64, 73 и 179, cf. Радојчић (ур.) 1960). Манастирске болнице и прихватилишта такође су били значајна средишта социјалног старања. Најстарије српске болнице биле су у Хиландару и Студеници, затим у Дечанима, Светим Арханђелима код Призрена, Раваници, Београду и другде. Подижући болнице и странопријемнице и старајући се о болесницима и сиротињи, српски владари су испуњавали јеванђеоске заповести, последовали Христу и тако градили овоземаљску светост која је услов за стицање оностране и којом су се укључивали у сакралну историју.

Скривене милостиње и доброчинства разликују се од других врста давања по томе што су искрен и несебичан чин. Оваква тајна давања су позната у многим културама. Давање милостиње, према Беседи на гори, треба да је тајно и нелицемерно (Мт 6,2-4). У античко доба се тајно давање етички проблематизује. Сенека у спису De beneficiis (око 60. н.е.) објашњава да добра дела која се чине невољнима треба да буду тајна. О давању не треба мислити као о улагању, него као о поклону који се даје тако да прималац од њега има највећу корист. Давање је задовољство по себи и оно не треба да жели јавне награде. Давалац треба да се уздржи од наговештаја да је дао милостињу и треба да одмах заборави да је дао, а прималац не треба никад да заборави да је примио (Seneca: Book II, X). Сличан став среће се у рабинским учењима која су такође поштовала достојанство сиротиње, чак су дозвољавала и да се превари сиромах који је сувише поно- 
сан да би примио милостињу тако што му се понуди тобожња позајмица која би била заборављена ако би је сиромах примио. И у Курану се спомиње да јавна и тајна давања, садака и зекат, чине обавезан део спасења.

Стари српски писци често приписују скривена доброчинства владарима и јерејима. Ови мотиви приказани су различито, од општег места до целовите и развијене сцене. Топос неизрецивости скривених дела користи Теодосије у Похвали светом Симеону и светом Сави. Питајући се зашто не може достојно да похвали сва добра дела светитеља, писац одговара: „Јер многа добра дела ваша у тајности и невидљива беху, видљива Јединоме - свевидећем скривених и испитивачу тајних" (Теодосије 1988а: 255).

На другом месту Теодосије описује како је Сава тајном молитвом исцелио брата Стефана:

Крст свети и часни омивши, том освећеном водом и топлом молитвом брата напоји, и свега га окропи, полажући руке своје свете на часну његову главу, и ову грлећи са сузама целоваше, много се молећи за њега тајно у срцу тајнозналцу и ономе који види сакривено. И молитвом светога спасе се болни, и наједанпут се исцели (Теодосије 1988: 202).

Тајна молитва је овде део поступка исцељења освећеном водом и показује како тече исцелитељски процес преноса божанских енергија.

Мотив тајне молитве користи и архиепископ Данило Други да би описао побожност и ревност краља Драгутина:

Јер шта да кажем о толику његову подвигу и трпљењу и ноћном стајању његову, молбама, молитвама и божанским песмама? Све ово чињаше стојећи на тајном месту и мучећи тело своје, слушајући реч Владике у светом еванђељу, који каже: Када се молиш, уђи у клет своју и затвори врата своја, и помоли се оцу твоме који је у тајни (Мт 6,6). Јер тако знајући чињаше (Данило Други 1988: 69).

Краљ се трудио да се моли у тајности:

А кад биваше време ноћнога пјенија да иде са збором у цркву, и према законском црквеном уставу на његову двору, он сам налажаше се пре свију у цркви, и пошто је ту свршио обична пјенија, и ако је ноћу рано било, опет 
је долазио на оно исто усамљено место, свршавајући све по достојању, како беше навикао (Данило Други 1988: 69).

Драгутин се припремао за монаштво презирањем тела, лежећи у гробу од оштрог камења и трња уместо у постељи. Краљев подвиг добија документарну вредност Даниловим сведочењем које је било тајно, а сад се објављује: „А ја, грешни Данило, био сам тајни зналац неких такових његових подвига" (Данило Други 1988: 69). Тајност је управо одлика праве вере и усрдности која у Драгутиновом случају потврђује његову жељу да се замонаши, што му се пред смрт и обистинило. Код Данила реч је о обавези духовника да саветима и саосећањем бодри на подвиг.

Наведени примери упућују с једне стране на обликовање лика монаха тј. духовника који кроз тајну молитву, „свесним стављањем себе у божје присуство отварајући ум и срце према њему” (Kazhdan 1991/3: 1713), остварује „сапостојање и јединство човека и Бога” (Богдановић 1968: 98). Тајна, унутрашња молитва може се интерпретирати у духу учења светог Јована Лествичника као молитва духа, исихастичка умна молитва која је највиши ступањ аскезе и којом „аскет утиче на збивања у свету” (Богдановић 1968: 96-98; Јован Лествичник 1993: 192-197). Отуд су посредством молитве могућа исцељења (свети Сава исцељује брата Стефана) и лични подвиг (краљ Драгутин). Молитва има своје ступњеве, од телесне до умне (молитва срца), као и технике о којима поучавају хришћански богослови. Симеон Нови Богослов препоручивао је да духовници, како би узрасли у молитви, треба да развијају проницљивост ( $\delta i \alpha ́ \alpha \rho l \sigma l \varsigma)$, милосрдну

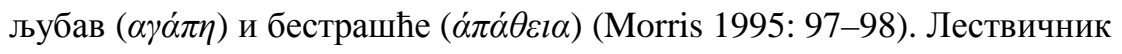
напомиње да је молитва могућа само уз милостињу: „Милостиња - то су крила молитве: ако својој молитви не даш крила, она неће узлетети у вис; ако ли окрилатиш своју молитву, узнеће се на небо" (Јован Лествичник 1993: 196). Треба напоменути да иако у оквиру аскетике скривена молитва има сложена значења, у народној побожности она може да се доживи као чудо које има сотериолошку улогу и утолико је, исто као и у хришћанском учењу, доказ божјег присуства на земљи. 
Развијена сцена скривене милостиње приказана је у неколико житија српских владара. Владари прерушени у просјаке одлазе ноћу да тајно деле милостињу. Архиепископ Данило велича краља Милутина због јавних задужбина и милостиња (био је „отац сиротих и заступник удовица, хранитељ гладних, одећа нагих, поборник увређених, утеха жалосних" - Данило Други 1988: 134), али истиче и његове тајне милостиње домаћима и странцима на које су га подстакле мисли о страшном суду и другом доласку Христовом. Краљеве ноћне походе Данило одређује као богољубазно и дивно чудо. Ноћна давања супротстављена су дневним даривањима, а и сам краљ мења идентитет: он дању носи царске хаљине, а ноћу се преоблачи у худу стару одећу и претвара се у понизног слугу који ревнује Христу.

А када је ноћ долазила, и пошто нико није знао овога богољубазнога и дивнога чуда, овај господин мој христољубиви свукавши са себе царске хаљине које је дању носио, и положивши на себе худу стару одећу, и прикривши лице своје да га нико не позна, и узевши са собом двојицу или тројицу неких верних својих слугу, којима беше заповедио да никоме не говоре што виде, и узе са собом велико мноштво злата и друге потребе, колико је довољно за давање убогима, да испуни утробе њихове сваким добрим даром двоструко, с једне стране као истинити хранитељ хранећи гладне, с друге стране као нелицемерни давалац милостиње, волећи ништа и убога. И тајно изишавши из двора свога, и дошавши посред станова њихових где су они спавали, и узимајући много злата даваше у руке њихове такође и храну и одело, а ови су се дивили и нису знали, откуда им је ово дано. Не знајући да је (то) добри њихов хранитељ, дању чинећи им милостињу, а у ноћи сам налазећи се посред њих, и као слуга стојећи пред њима, ревнујући љубитељу своме Христу, који се смирио и узео слику слуге (Данило Други 1988: 134).

Данило гради лик краља Милутина као ревнитеља Христу, што је уобичајено поређење у склопу топоса скривене милостиње. У средњовековном свету угледање на Христа (imitatio Christi) било је обавеза свих људи, а посебно цара, миропомазаника Господњег (Christus Domini). Владари су се трудили да свој живот и делање што више уподобе Христу и да му наликују у врлинама, да буду „отелотворење божанских врлина". Једна од необично важних врлина је божанска журба - хитрост у милосрђу (Пс 72,6) коју покушавају да подражавају и цареви (rex prosperans). Почев од Стефана Немање, сви стари 
српски владари су тежили идеалу журбе (nоташтаније, поспешеније, поревнованије) у добрим делима, задужбинама, подвизима, милостињама (Марјановић-Душанић 1997: 254-264).

Одређење Милутинове скривене милостиње као чуда није тек реторска фраза. Мада нема атрибут класичног светитељског чуда у смислу манифестације спољне фантастике, краљева тајна милостиња је непосредан доказ сакралности самог чина даривања, али и светости краља који се даривањем уподобљава Христу. Другим речима - милостиња је чудо јер је доказ присуства божанске милости у чину даривања и уједно краљеве богопозваности и благочастивости. Милост је божанско својство које се дарује људима и када се преноси даље, само се враћа Богу оно што је он дао. Христос каже апостолима: „Болесне исцјељујте, губаве чистите, мртве дижите, ђаволе изгоните; забадава сте добили, забадава и дајите” (Мт 10,8).

Јавну и скривену милостињу и доброчинства Милутиновог сина Стефана Дечанског описао је Григорије Цамблак. Краљ обилази и дарује болеснике дању, али и ноћу, прерушен у војника. Он се припрема за духовни подвиг и пружајући утеху страдалницима, сам од њих прима поуке.

А и сам често долажаше, једном правећи се да је неки од војника, и дајући овима довољно новца, а други пут и јавно дању. Клањајући се овима грлио је усрдно она састрадатељна тела, целујући их са сузама, говорећи им речи утехе и хвалећи их што се ради привременог страдања и које брзо пролази, удостојише бесконачнога царства. И ни Соломон се у свој слави царства свога не слављаше (Мт 6,29; Лк 12,27) колико он овим сабрањем страдалника, и многе ноћи провођаше беседећи с њима, јер беху међу њима мужеви, који су се удостојили неким божаственим даровима (Григорије Цамблак 1989: 70).

Развијен опис доброчинстава и скривених милостиња деспота Стефана Лазаревића дао је Константин Филозоф. Стефанови ноћни походи конкретизовани су у две епизоде којима време није одузело ништа од свежине и снаге. Константиново приповедање је непосредно и драмско, дијалози су живи, детаљи изоштрени, а психологија префињена. Опис одаје утисак документарног сведочанства из прве руке, а у исто време служи као „објава истине” - објава сакралног и по- 
тврда божанске светости (,jер нема ништа скривено што се неће открити, ни тајно што се неће дознати", Мт 10,26).

И његово дело беше непрестана милостиња и често читање божанских речи. Толико се бринуо за ниште да је сам излазио ноћу по путевима и оградама да даде милостињу својом руком. И само онога који носи злато или сребро, што је баш било, само једнога највернијега са собом узимаше, а много пута и сам ово чињаше.

Када једном приђе један ништи, (деспот) му даде (милостињу). А (овај), опет, претекавши (га), прошаше. Блажени, познавши (га), даде му још више. Он (га) и трећи пут претече, (Стефан) му даде још више рекавши: „На, грабљивче и варалицо!” А овај одговори: „Нисам ја грабљивац и варалица, јер ми је невоља, него ти који земаљским царством царствујеш, небесно (царство) крадеш и грабиш". А прилажаше и вратима ништих, којима кроз прозорчић и отвор (милостињу) даваше. И сви знађаху ко је тај који ово чини. Хођаше свагда велика гомила прокажених које сам свагда храњаше и у ноћи њихове деснице (даровима) испуњаваше.

И да истина буде још јасније објављена. Једном, чувши за ово, дођоше прокажени од поморских страна и бугарских, толико много да су силом пљачкали грађане, они (прокажени) су се и били са управитељем града; и изгнаше их. Ради тога били су и одагнани.

А још дела своја знамењем њиховим непрестано обележаваше. Једном хтеде да изађе да (као и) обично, чини милостињу и када су сви напољу и унутра спавали, узе са собом једнога веома (себи) омиљеног, који је знао и остале тајне, и рече му: „Потајно узми истовремено (и) мач мој”. А тај није разумео шта му је заповеђено, а питати није смео; и донекле заједно ишавши, остави га рекавши: „Почекај овде!” И негде у саму дубоку ноћ врати се к њему; и дођоше до унутрашњих врата, која, кад је млађи хтео да (их) отвори, није могао брзо. А деспот, мислећи да држи његов мач, заповеди да га држи другом руком. И рече му: „Дај мени мач док не отвориш”. А млађи тада разумеде шта му је било речено, уплаши се говорећи: „Не смета ми ништа”. Затим отворивши изађе брзо лествицом да напред осветли; и чинило се као да оставља мач правећи се као да ништа о (мачу) не зна. Беше благочастиви ушао у дубину (некаквог) брлога; овакве ствари његове не могу се избројити, као ни морски песак. Ово није престајао чинити за све дане свога живота. Да не спомињемо у пустињама по васељени и у пределима његовим (и) у атонским, где за кога слушаше да живи у Господу, све пустињаке, усамљенике и општежитељнике, ако је ко (од њих) молио кадионицу или који драгоцени светилник, (и) да се носи тамо, молио је начелника тога места: „Ја ћу 
много скупоценији и светлији (светилник) овде убрзо дати ако ово даш", и убрзо извршаваше све што је рекао. Ови и остало (тј. дарове) неоскудно добијаху. Доста је речено о овом (Константин Филозоф 1989: 117-118).

Прва епизода приказује Стефана како дајући сиромаху стиче небеско царство (према јеванђеоској заповести: „Продај све што имаш и раздај сиромасима; и имаћеш благо на небу”, Лк 18,22; Мт 6,20), са заменом смисла: не граби грабљивац који прима милостињу, него онај ко граби царство небеско. У другој епизоди Стефан одлази тајно и сам, оставивши мач, симбол власти.

Испитујући митске мотиве у традицији о деспоту Стефану, Веселин Чајкановић је указао да се Стефан и у народним предањима приказује слично као у Житију. Према једном запису из Херцеговине, Стефан се преобукао у просјака и просио по свету: „Гдје год је срео богаташе, узимао је од њих што су му давали, а гдје год би сретао сиромашне, све би им давао, и више двојином давао би сиромашним него што би узимао од згодних" (Чајкановић 1927: бр. 146, 389). Тако је чинио све док га немачки цар није препознао (овде је реч о фамилијаризацији - алудира се на аустроугарску владавину, будући да се приповедање осавремењује према реалијама из свакодневице казивача). И кад је цар упитао Стефана зашто је преобучен у просјака, он је одговорио: „Идем стога да видим како свијет живи, препознају ли и помажу ли згоднији сиромашнима и да се не зауставих код тебе и не казах се, још бих дуго и далеко тако по свијету ходио и просио" (Чајкановић (ур.) 1927: бр. 146, 390).

Чајкановић је запазио да је приповедач овог предања схватио до-

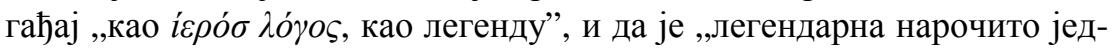
на црта: то је херој у просјачком оделу". У тој легенди он је препознао универзални сиже о божанствима или демонима који преобучени у просјаке иду по свету и искушавају људе. Велики број примера хероја преобучених у просјаке он налази у митологији, фолклору и књижевности, почев од Одисеја и Алексија Божјег човека до народних песама и приповедака, као и њима блиске примере да се божанства јављају у лику путника (анђели у старозаветним причама о Авраму и Лоту, Јупитер и Меркур у Филемону и Баукиди и др., Чајкановић 1994: 275). Пошто је коментарисао и друге теме везане за деспота Стефана (предање о рођењу јунака и судбинској одређености), Чајка- 
новић закључује да је ,личност деспота Стефана још врло рано добила митски карактер”. Као свети Сава и Марко Краљевић, тако је и Стефан приказан као културни јунак, старинско божанство које путује земљом и куша, награђује и кажњава људе. Будући да је и историјски Стефан био неуморни путник, предање то објашњава на свој начин. Фолклорни лик деспотов надмашио је месне оквире - приче о њему забележене су далеко од његове уже области (у Херцеговини, Босни, на Приморју), па је у том процесу преношења Стефан постепено добијао митске атрибуте (Чајкановић 1994а: 91). Мада Чајкановић види могући узрок везивања мотива божанског путника за деспота Стефана у историјским сведочанствима о многобројним деспотовим путовањима, он не спомиње наведени одломак о скривеном давању милостиње из Константиновог Житија који је вероватно утицао да се у народној побожности створи представа о Стефану као о милосрдном владару, независно од тога што је он званично канонизован тек 1927. Наиме, сфера утицаја Константиновог дела била је сигурно већа него што се на први поглед може закључити на основу неколико сачуваних преписа опширне и кратке редакције и фрагмената укључених у руски Хронограф, па се може претпоставити да је мотив Стефанове скривене милостиње продро у усмену традицију.

Описи Стефановог даривања, а посебно епизода тајног даривања и „грабљења" небеског царства, привлачили су пажњу каснијих писаца, нпр. непознатог састављача Троношког родослова и Јована Рајића. Владарске врлине, какве су давање милостиње и брига о угроженима, радо истичу хагиографи, летописци и хроничари јер оне имају сотериолошку улогу и сведоче о спони између владара и божанских сфеpa. Тако је и писац Троношког родослова пренео и допунио Константинов опис Стефанових задужбина и доброчинстава и унео епизоду тајног даривања, али се и одвојио од Константиновог изворника. Он мотивише зидање манастира деспотовом бешчедношћу, што се може схватити као поступак човека народне културе који као да не мари за чињеницу да је зидање манастира дужност владара, него надовезује причу у складу с народним веровањем да се задужбине зидају за спас душе или да би се окајао какав грех. Непознати писац се разоткрива и као сведок свог времена који зна да је Манасија утврђена с три ограде, да је тамо деспот сахрањен и да су многи деспотови манастири 
разрушени, и они у Београду, а да се око Каленића и Манасије често може срести турска стража. У епизоди о скривеној милостињи такође се препознају фолкорне црте:

Gказ8етса W Превекикой мипостины сего Gтефана, гакW всеГАа, ЕГАа Живаше

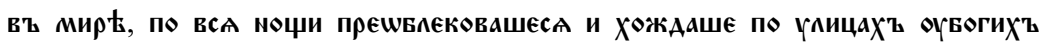

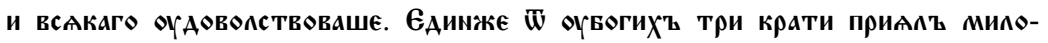

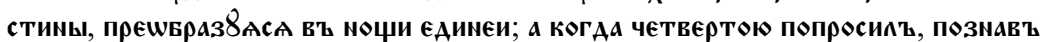
егw Gтефанъ, и глаголаше ем8: Хиштниче и тат8 оүвшгихъ, какш неоувоишиса вога, крад 8 ћи мазА 8 имихъ оүвогихъ. Тойже Швђчавъ ем8: га во сревро твоє и частъ вратіи моихъ крад 8 , тиже сревромъ тимъ крадешъ царство невесное (Шафарик 1853: 98-99).

Епизода о скривеној милостињи пренета је на начин типичан за усмено приповедање, с препознатљивом уводном формулом (,,сказујетсја" - што упућује на ауторитет традиције као извора) и употребом дијалога, и с тежњом да се стилски заокружи поента. Писац додаје нешто чега у Константиновом изворнику нема: то је Стефанов прекор упућен грабљивом сиромаху да је крадљивац убогих јер им отима награду, док позив на страх божји уноси моралистичке конотације. Изостављајући мотивацију коју даје Константин (,,јер ми је невоља”, у оригиналу „страсти належет ми”), он мења и смисао његове похвале (,ти иже земљаним царствујеј и небеснаја крадеши и васхиштајеши" - Јагић, Трифуновић (ур.) 2004: 309). У Троношком родослову лик грабљивца прераста у лик крадљивца који је у још оштријем контрасту према деспотовој врлини.

О Стефановим доброчинствима и тајној милостињи пише и Јован Рајић у чувеној Историји словенских народа. Он релативно верно преноси текст према Константиновом Житију које назива Цароставник, односно Историја наша ва старих неких рукописех неизвестнаго ауктора (Рајић 1823: 111).

Описи Стефанове скривене милостиње из Троношког родослова и Рајићеве Историје илуструју како се у 18. веку ови топоси преносе у истом значењу које су имали и у делима изворницима. Ове топосе треба посматрати као део уметничке реторике, у контексту средњовековне топике која се наставља на византијску и античку. Топоси скривене милостиње припадају широкој групи топоса о светитељима као 
помоћницима у земаљским невољама. У црквеној поезији, похвалним и другим списима светитељи се означавају овим одредницама: сирим и ништим и вдовицам отац, питатељ, богатство, заступник, благодатељ, помиловање, заштитник; слепим вожд, око; скрбним и скрбештим помоштник; плачуштим утешеније; болештим утешеније; старости жазл; хромим нога; нагим одејаније, алчуштим питатељ итд. (Трифуновић 1990: 212). Писци 14. и 15. века развијају топосе скривене милостиње у духу средњовековне поетике похвала владару и хришћанске идеје спасења: „Пазите да правду своју не чините пред људима да вас они виде; иначе плату немате од оца својега који је на небесима" (Мт 6,1). Ови топоси се у основним цртама темеље на чињеничним сазнањима о старању средњовековних владара о убогима која су посведочена у историјским и правним изворима, али се у исто време уклапају у програм владарске политичке идеологије који се заснива на много старијим обрасцима. Топоси се оживљавају документарним казивањима, „причама из живота” које сликају владарево милосрђе. У описаним епизодама скривених даривања Милутина, Стефана Дечанског и Стефана Лазаревића модел је сличан, али се појединости разликују управо према врсти светитељског програма који хагиограф жели да представи. Данило приказује скривене милостиње краља Милутина као један у низу његових подвига који ће му омогућити да буде препознат као светитељ, при чему се истиче карактеристично угледање на Христа и обртање улога: Милутин је слуга сиромасима исто као што је Христос слуга истине ради (Рим 15,8). Цамблак пак приказује ноћне милостиње Стефана Дечанског као део његовог духовног раста на путу ка светости. Константин Филозоф конкретизује примере Стефанове скривене милостиње приказујући га реалистички, као брзог и делатног помоћника и доступног спаситеља. Моделима скривене милостиње заједничко је то што су у њиховом средишту владари-борци за небеско царство, милостиви дародавци који су заправо само посредници у преношењу божанских дарова. У том смислу је скривена милостиња спона између људи и божанства jep, како пише Старобински, „економија дара је кружење које не сме бити прекинуто" (Starobinski 2009: 109). Заједничка црта је и прерушавање владара, мотивисана јеванђеоским захтевом за тајношћу давања који је синоним за скромност, искреност, нелицемерје. У ширем 
смислу, прерушавање би могло да има и ритуалну нијансу: владар преузима идентитет сиромашних да би посредовао божанску милост, јер у вертикалном даривању сви људи су слуге божје, нема разлике између краљева и слугу, богатих и сиромаха.

Идеологија топоса скривеног давања, онако како је уметнички транспонована у наведеним примерима, има улогу да представи даривање милостиње као морални чин избора, не као дужност. Скривена милостиња није трансакција између богатих и сиромашних, јаких и слабих, него између једнаких. Она дозвољава да се задржи људско достојанство у давању исто као и у примању, и да се оствари равнотежа у кружењу дарова.

\section{Литература}

Библија или Свето писмо Старога и Новога завјета, 1968, прев. Ђ. Даничић, В. Стеф. Караџић, Београд s.a.

Богдановић Д., 1968, Јован Лествичник у византијској и старој српској књижевности, „Стара српска књижевност” књ. 11, Београд.

Григорије Цамблак, 1989, Кьижевни рад у Србији, прир. Д. Петровић, прев. Л. Мирковић, Д. Богдановић, Ђ. Трифуновић, „Стара српска књижевност” књ. 12, Београд.

Данило Други, 1988, Животи краљева и архиепископа српских. Службе, прир. Г. Мак Данијел, Д. Петровић, „Стара српска књижевност” књ. 6, Београд.

Јагић В., Трифуновић Ђ. (ур.), 2004, Константин Философ и юегов Живот Стефана Лазаревића деспота српскога, прир. Ђ. Трифуновић, Горњи Милановац.

Kazhdan A.P. (yp.), 1991, The Oxford Dictionary of Byzantium, vol. 1-3, New YorkOxford.

Константин Филозоф, 1989, Повест о словима. Сказаније о писменех: изводи. Житије деспота Стефана Лазаревића, прев. Г. Јовановић, Л. Мирковић, „Стара српска књижевност" књ. 11, Београд.

Лествичник Ј., 1993, Лествица, прев. Д. Богдановић, „Хиландарски преводи” бр. 5, Манастир Хиландар.

Марјановић-Душанић С., 1997, Владарска идеологија Немањића. Дипломатичка студија, Београд.

Morris R., 1995, Monks and laymen in Byzantium, 843-1118, Cambridge-New York. 
Патлажан Е., 2006, Сиромах, у: Византинцฺи, прир. Г. Кавало, прев. С. Ђураковић et al., Београд.

Радојчић Н. (ур.), 1960, Законик ияара Стефана Душана 1349 и 1354, издао и превео Н. Радојчић, Београд.

Рајић J., 1823, Исторія разныхъ славенскихъ народовъ, наипаче же Болгаръ, Хорватовъ и Сербовъ, изъ тмы забвенія изятая и во свьть исторіческій произведенная, Въ Будиномъ градь.

Seneca, L. Annaeus Seneca On Benefits, ed. A. Stewart, <http://www.gutenberg.org/ca talog/world/readfile?fk_files=3221892>, 10.11.2012.

Starobinski Ž., 2009, Darežljivost, prev. M. Vuković, Sremski Karlovci-Novi Sad.

Шафарик Ј., 1853, Србскій льтописацъ изъ почетка ХVІтогъ стольтія, „Гласникъ Друштва Србске Словесности” V, Београд.

Теодосије Хиландарац, 1988, Житија, прир. Д. Богдановић, прев. Л. Мирковић, Д. Богдановић, „Стара српска књижевност” књ. 5, св. 1, Београд.

Теодосије Хиландарац, 1988а, Службе, канони и Похвала, прир. Б. Јовановић-Стипчевић, прев. Д. Богдановић, Б. Јовановић-Стипчевић, „Стара српска књижевност" књ. 5, св. 2, Београд.

Трифуновић Ђ., 1990, Азбучник српских средњовековних књижевних појмова, Београд.

Чајкановић В., 1994, Студије из српске религије и фолклора (1910-1924), прир. В. Ђурић, Београд.

Чајкановић В., 1994а, Студије из српске религије и фолклора (1925-1942), прир. В. Ђурић, Београд.

Чајкановић В. (ур.), 1927, Српске народне приповетке, „Српски етнографски зборник” књ. 41, Београд. 
